\title{
Pedagogical conditions for supporting gifted children in Yakutia (on the example of the Higher School of Music of the Republic of Sakha (Yakutia))
}

\author{
Ekaterina Pavlovna Pavlova ${ }^{1,}$, , Sofya Nikolaevna Shadrina ${ }^{1}$, Zinaida Grigorievna Pavlova ${ }^{2}$, \\ Raisa Ilyinichna Vasilieva $^{2}$, and Victoria Aleksandrovna Pavlova ${ }^{1}$ \\ ${ }^{1}$ North-Eastern Federal University, Yakutsk, Russia \\ ${ }^{2}$ Higher School of Music of the Republic of Sakha (Yakutia) (institute), Yakutsk, Russia
}

\begin{abstract}
The article highlights the problems of developing giftedness in children and approaches to support them in Yakutia. The problem of educating gifted children and creating conditions for the evolution of their unique potential is becoming one of the main modernization areas in the Russian education system. The study goal: to study the situation of supporting musically gifted children of Yakutia. Research methods: study and analysis of theoretical sources, Russian and foreign experience in supporting children's giftedness, processing and analysis of statistical data, analysis of experience in supporting children's giftedness in Yakutia. The scientific novelty of the research consists in teaching musically gifted children and studying their phenomenon through the prism of a system of pedagogical conditions that ensure their personal growth on the basis of a Higher School of Music and a general education institution that provides training at three successive levels of education: primary, secondary and higher. The study result is based on the analysis of the researchers' views, we attempted to systematize knowledge about giftedness, a set of measures to accompany musically gifted children held in the Republic of Sakha (Yakutia) were highlighted and the pedagogical conditions reflected in the recommendations were identified.
\end{abstract}

\section{Introduction}

Having analyzed the studies of Russian and foreign research aimed at studying childhood giftedness, it can be observed that the concept of childhood giftedness is defined by each study in a diverse and contradictory way. In the theory of pedagogy and psychology, there is no consensus on what determines the most unique child's abilities - individual innate personality traits or its formation under the influence of social and external conditions. In either case, the modern definition of situation in the creative psychology problems is characterized by a mixture of different statements.

\footnotetext{
${ }^{*}$ Corresponding author: eppavlo2010@rambler.ru
} 
The term "giftedness" is used to define a child's intellectual, creative, and motivational abilities. Many researchers define giftedness, for example, with the help of achievements: grades in school or high scores received in Olympics and competitions. Indeed, most would agree that a child who can read at age three, plays chess at age six, or plays the violin and orchestra at age eleven is gifted. These examples demonstrate children who are ahead of their evolution, which is undoubtedly one of the most important signs of giftedness. Hidden potential and the achievement of success that lies in the child, contribute to two factors: external (family circle, class and school community, society, culture, stressful situations) and internal (learning and stress strategy, motivation to achieve, ability to experience emotions, work and prevention of stressful conditions). Research of A. Ziegler and H. Stoeger showed the effectiveness of external factors in the early stages of training. Then, in the later stages of learning, external factors should begin to interact with internal factors to turn existing potential into real achievements.

Many countries around the world have long recognized the effectiveness of educational programs to support and develop gifted children and to this day create further conditions for fulfil their potential. A recent study conducted in the United States found that most of the country's political, financial and managerial elite graduated from top educational institutions and are academically and intellectually gifted [2]. The educational reform in China specifically singles out the creative elite so that in the future they will take leading positions in politics, science and economics [3]. According to N.V. Meshkov, the administrative resources given by the state, although play a significant role in the gifted children' education, are not enough for the full disclosure of the potential and achievements of each gifted child [4].

To accurately identify and develop gifted children, programs and institutions such as the Psychology of Giftedness Laboratory at the Psychological Institute of the Russian Academy of Sciences, the targeted training federal program "Gifted Children", and others were developed as a response to the trend of the need for special training for gifted children. As a result, the number of practice-oriented studies M. Matyushkin, A.I. Savenkov, D.V. Ushakov, M.A. Kholodnaya, V.S. Yurkevich et al) and research aimed at finding psychological patterns of giftedness and mechanisms of its development has increased.

Both among psychologists in the field of musical predisposition studies and among musicians themselves, different and diverse ideas about musical giftedness are common in Russian pedagogical science. According to some of them, musical giftedness - the highest and most individual manifestation of musical abilities. The concept of musical giftedness includes: instantaneous, phenomenal memory, a brilliant ear for music and a sense of rhythm, a flexible and coordinated motor "apparatus", incredible diligence, easy learning and performance [5]. Unfortunately, our country's established experience in the development of gifted children, including music education, specializes exclusively in the methodology of teaching the subject. Nevertheless, some studies (D.B. Bogoyavlenskaya, N.S. Leites, K.K. Platonov, Ya.A. Ponomarev, V.Z, S. Yurkevich et al.) show that it is the development of the child's personality, character traits and psychological features that take the leading role in identifying and realizing potential in various areas of their activities. Often, such studies focus on the dynamics of manifestation, progress and development of creative giftedness. However, due to its narrow focus, the problem of educational institutions in the development of artistically (in particular, musically) gifted children is dissembled [6].

\section{Materials and methods}

To achieve our research goal, we will highlight the activities of the state budgetary educational institution of higher education "the Higher School of Music of the Republic of Sakha (Yakutia) (institute) named after V.A. Bosikova". The ideological mastermind of the 
development of the Higher School of Music was the First President of the Republic M.E. Nikolaev. Also, his name is associated with activities to support and organize the training of gifted children in order to expand the professional sphere in the field of music education and the training of highly qualified musicians. Over the years, a network of professional ensembles and musical cultural institutions of the republic has been formed. Such as, the State Philharmonic of the RS(Ya); the State Ensemble of Violinists "Virtuosos of Yakutia", created on the basis of school; symphony and wind orchestras, string ensemble "Arco ARTico", "Camerata Yakutsk", brass quintet. The lack of orchestrators and performers has been addressed at the State Theater of Opera and Ballet of the Republic of Sakha (Yakutia), the National Dance Theater of the Republic of Sakha (Yakutia) named after S.A. Zverev; State Circus of the Republic of Sakha (Yakutia); in the Aldan State Concert Orchestra, vocal ensemble "Tuimaada".

The Higher School of Music represents a unique, Russia's only, three-stage model of educational institution: in grades I-IX, pre-professional musical training is carried out at an advanced level, together with the general education development; in grades X-XI, the music college program is implemented; in the university, students are trained in Bachelor's and specialist's program.

Active concert activity of students of the school is an integral part of the educational process. Notable is the fact that they not only take part in music competitions of various levels, but many of them become laureates and diploma holders of competitions at the regional, all-Russian and international levels.

The expert community of Russia highly appreciated the ongoing educational program for the training of specialists in music in Yakutia, noting the inclusion in the Russian directory "The best educational programs of innovative Russia" and the national register "Leading Cultural Institutions of Russia”.

On the basis of the Higher School of Music since 2013, a national interagency project "Music for all" is being implemented under the joint supervision of the Ministry of Culture and Spiritual Development of the RS(Ya) and the Ministry of Education and Science of the Sakha (Yakutia), in preparation for the 100th anniversary of the YASSR, based on the strategic UNESCO developments in music education. According to the Concept, the project implementation mechanism is carried out in three stages: 1)The first stage - 2013-2014 - the work and creation of the necessary regulatory framework and interdepartmental activities for the project implementation; 2) The second stage - 2015-2020 - the practical work stage; 3) The third stage - the final, 2020-2022 - the study and generalization of the accumulated experience; achievement of the expected results, that is, the education of each student as a competent listener, lover and judge of music, with basic skills of playing musical instruments, as well as the creation of creative teams on the basis of secondary schools.

To achieve the study goal, we identified the following tasks: study and analysis of theoretical foreign and domestic sources of researchers on the problem of giftedness; study of available experience in identifying and supporting musically gifted children in the Republic of Sakha (Yakutia); analysis of statistics for the period 2016-2019, and determination of factors influencing their dynamics; discussion of the results and development of recommendations. In conducting this study, we used the following methods of theoretical research: study and analysis of foreign and Russian psychological, pedagogical and special literature; analysis and systematization of information and pedagogical and educational materials on the topic of research and education in Russia and foreign countries; empirical methods: observation, psychological and pedagogical and statistical and mathematical analysis of information given in official documents that accompany the educational process. 


\section{Results and discussion}

The phenomenon of child giftedness, first of all, is a multidimensional phenomenon characterized by the accentualization of the leading activity in ontogenesis. Scientific research aimed at the specific conditions of support, the development of individual trajectory of gifted children in the school, family and environment. Qualitative indicators of the development of gifted children allow to reveal the phenomenon of giftedness, including musical, which we interpret as a systemic quality that characterizes the child's psyche as a whole, its involvement in musical activity. At the same time, it is the personality, its focus, the system of values that leads to the development of abilities and determines the further realization of its potential. At the same time, it should be noted that not always high mental abilities alone provide a creative level of individual's activity.

Considering the issue of giftedness in musical art, it should be noted that the selection to the Higher School of Music of the RS(Ya) is based on determining the level of musical abilities, such as emotional responsiveness, harmony sense, musical rhythmic sense, sound and pitch (register and melodic) sense, formative sense. To identify giftedness, it is necessary to analyze the development of a particular child, a more appropriate form of identification with the signs of musical giftedness of a particular child. Revealing the structure of musical giftedness on the one hand provides an opportunity for reliable prediction, on the other hand allows to identify factors blocking its formation, as well as the uneven development of musical - operational components: their underdevelopment and sources of compensation.

The recruitment of children to the Higher School of Music of the RS(Ya) is carried out from all over the republic, in this regard, the creation of a database of gifted children of the state budgetary educational institution "Higher School of Music of the RS(Ya) (institute) n.a. V. A. Bosikov" contributes to their further development of creative and personal growth. We present data on the program "Young Talents of the Arctic", showing the mechanism of gifted children selection from remote Arctic uluses in 2016-2019.

Table 1. The number of children entered in the Higher School of Music of the Republic of Sakha (Yakutia) (Higher School of Music of the RS(Ya)) for 2016-2019

\begin{tabular}{|c|c|c|c|c|c|}
\hline No. & $\begin{array}{l}\text { Uluses (districts) of } \\
\text { the Republic of } \\
\text { Sakha (Yakutia) }\end{array}$ & $\begin{array}{l}\text { Units of } \\
\text { measurement }\end{array}$ & $\begin{array}{l}\text { The number of } \\
\text { people who } \\
\text { wanted to enter } \\
\text { in the Higher } \\
\text { School of } \\
\text { Music of the } \\
\text { RS(Ya) }\end{array}$ & $\begin{array}{l}\text { The number of } \\
\text { recommended } \\
\text { children to study at } \\
\text { the Higher School } \\
\text { of Music of the } \\
\text { RS(Ya) }\end{array}$ & $\begin{array}{l}\text { Number of } \\
\text { students who } \\
\text { started classes } \\
\text { at the Higher } \\
\text { School of } \\
\text { Music of the } \\
\text { RS(Ya) }\end{array}$ \\
\hline 1. & Abyysky & children & 115 & 9 & 2 \\
\hline 2. & Allaikhovsky & children & 102 & 6 & 1 \\
\hline 3. & Anabarsky & children & 91 & 6 & 0 \\
\hline 4. & Bulunsky & children & 69 & 1 & 0 \\
\hline 5. & Verkhnekolymsky & children & 73 & 4 & 0 \\
\hline 6. & Verkhoyansky & children & 96 & 4 & 0 \\
\hline 7. & Zhigansky & children & 172 & 9 & 2 \\
\hline 8. & Momsky & children & 107 & 7 & 1 \\
\hline 9. & Nizhnekolymsky & children & 103 & 3 & 0 \\
\hline 10. & Oymyakonsky & children & 50 & 6 & 0 \\
\hline 11. & Oleneksky & children & 236 & 8 & 0 \\
\hline 12. & Srednekolymsky & children & 145 & 11 & 1 \\
\hline 13. & Ust-Yansky & children & 160 & 8 & 0 \\
\hline 14. & Eveno-Bytantaysky & children & 123 & 6 & 3 \\
\hline & Total number & children & 1642 & 88 & 10 \\
\hline
\end{tabular}

Table 1 shows that in 2016-2019, out of 34 uluses (districts), children from 14 Arctic uluses (districts) of the republic participated in the selection for admission to the Higher 
School of Music, in the number of 1642 children and only $0.6 \%$ (10) of children were entered and are currently studying. Consequently, the identification of musically gifted children is a complex nature of identifying and evaluating different aspects of child musicality and giving the ratio of specific quantitative statistics of those who want to enter and passed the selection can not fully reflect a definite trend of growth or, conversely, a decline in the number of gifted children. Also, not always successful general learning activities are associated with the giftedness development, more often it is a special ability, in this case the musical, developed in a narrowly focused activity. It is not uncommon for a student who is not very successful in public school to show brilliant results in the musical field.

At the same time, it is the competitions that reflect children's achievements that are indicators of the creative development of young musicians. The Higher School of Music of the $\mathrm{RS}(\mathrm{Ya})$ is the initiator of many creative projects. Among them are the Republican open competition of young performers "New Names of Yakutia" (1996), the International Youth Competition "Violin of the North" (2009), the Easter festival "Golden Domes" (2002), the international festivals "Eurasia. Dialogue. Classics" and "Classics of White Nights". Of these, the most sustainable are such mass fundamental projects as the Republican Open Competition of Young Performers "New Names of Yakutia" and the International Youth Competition "Violin of the North". Of all the republican competitions held nowadays, the competition "New Names of Yakutia" has some features that distinguish it from other creative competitions, having grown into a large multi-project, where each nomination is, in fact, an independent competition with its own requirements and evaluation criteria.

Processing and analysis of official statistics for three academic years in the period for 2016-2019 showed that 372 participants from 47 schools of the republic took part in the competition "New Names of Yakutia" in the 2016/2017 academic year, in the 2017/2018 academic year - 375 participants from 52 schools of the republic, and in the 2018/2019 academic year - 390 participants from 33 schools of Yakutia. Table 2 presents the number of participants in the official categories of the competition: "Piano", "Orchestral string and bowed instruments", "Orchestral wind instruments", "Academic singing", "Folk instruments", "Young Theorist", "Young Composer", "Choreography", "Folklore”, "Teacher and Student", "Music for all".

Table 2. The number of children who participated in the Republican open competition of young performers "New Names of Yakutia"

\begin{tabular}{|c|c|c|c|c|}
\hline \multirow{2}{*}{$\begin{array}{l}\text { Official nominations of the } \\
\text { contest "New Names of } \\
\text { Yakutia" }\end{array}$} & \multirow{2}{*}{$\begin{array}{c}\text { Unit of } \\
\text { measurement }\end{array}$} & \multicolumn{3}{|c|}{$\begin{array}{c}\text { Number of participants in the competition by } \\
\text { academic year }\end{array}$} \\
\hline & & $\begin{array}{c}2016 / 2017 \\
\text { academic year }\end{array}$ & $\begin{array}{c}2017 / 2018 \\
\text { academic year }\end{array}$ & $\begin{array}{c}2018 / 2019 \\
\text { academic year }\end{array}$ \\
\hline Piano & participant & 48 & 43 & 29 \\
\hline $\begin{array}{l}\text { Orchestral string } \\
\text { bowed instruments }\end{array}$ & participant & 18 & 18 & 47 \\
\hline $\begin{array}{ll}\begin{array}{l}\text { Orchestral } \\
\text { instruments }\end{array} & \text { wind } \\
\end{array}$ & participant & 33 & 60 & 38 \\
\hline Academic singing & participant & 29 & 28 & 60 \\
\hline Folk instruments & participant & 43 & 49 & 32 \\
\hline Young theorist & participant & 10 & 0 & 12 \\
\hline Young composer & participant & 18 & 0 & 16 \\
\hline Choreography & participant & 38 & 0 & 0 \\
\hline Folklore & participant & 125 & 66 & 73 \\
\hline Teacher and student & participant & 10 & 25 & 15 \\
\hline Music for everyone & participant & 0 & 86 & 68 \\
\hline
\end{tabular}

The analysis of the data from Table 2 allows us to state an increase in the total number of contestants due to the high number of contestants of string instruments and vocalists. At the 
same time, the number of competitors in the traditionally popular competition among pianists has significantly decreased. But analyzing the data for three academic years, it is difficult to objectively assess the real picture of the competition process dynamics. This factor can be associated with the fact that creative competitions of international and all-Russian level are held on approximately the same calendar schedules. Traditionally, students of the Higher School of Music of the RS(Ya) actively participate in them.

Work with gifted children on the territory of the Russian Federation and the Republic of Sakha (Yakutia) is a priority area for the development of the education system as a whole. Thus, as part of the National Project "Education" and the national educational initiative "Our New School" is supporting talented children. In the works of B.D. Kritsky, V.G. Razhnikov, V.P. Sradzhev, L.B. Shkolyar, G.M. Tsypin, et al. studies of problems of general and special music education are presented. They note that in special music education, individual pedagogical work and existing teaching experience are directed toward the professional musician development as a whole. In this case, the student's personal growth is not emphasized, due to the fact that many teachers have no understanding of the features of personal and creative development of students, therefore, the influence on the student's personality in education and training is practically non-existent.

Existing works of N.S. Leites, D.V. Ushakova, M.A. Cold, B.C. Yurkevich, E.L. Yakovlev et al., are devoted to the study of the development of general and children' creative giftedness and are of particular value in psychological science. But at the same time, we believe that the problem of personal formation and development of musically gifted children remains undiscovered. As a consequence, there is a contradiction between the need to create a favorable environment for the development of musically gifted children and the lack of scientific justification of the contributing psychological and pedagogical conditions and lack of attention to the development of their personality. On this basis, we expect that the education of musically gifted children can be successful with an integrated approach to the educational process, which takes into account the personal and creative development of students in a specialized educational institution. The development of talent among high ability students requires more than general intellectual development, to help stimulate the development of gifted children, they should learn among like-minded people with common interests and goals. This practice increases motivation among musically gifted children. Schools need to have the resources to support large numbers of gifted children. Of course, for most schools with limited resources and funds, many students with high ability go unnoticed.

\section{Conclusion}

It is known that the giftedness of children progresses if they are in a homogeneous environment of intellectual development. Thus, it can contribute to their academic success in various disciplines, at the same time, their social interaction is enhanced, because giftedness implies abilities that, combined with certain personal characteristics and a favorable environment, inflame in people the ability and need for self-education in various fields [7]. However, there is no consensus in research as to whether gifted children are comfortable in special or common classes. Researchers differ in their views, some of them argue that the gifted should be educated in an environment of children with more singular intellectual abilities [8], where they can avoid certain social conflicts, such as pinning labels, motivational and emotional problems. In the works of German authors, F. Preckel And K. Vogl, it is noted that gifted children who are taught under comfortable conditions for them, that is, in special classes, have an increased interest in learning, because here the teacher has an opportunity to interact with them individually and to meet their educational needs. Consequently, researchers emphasize the comfort and coexistence of gifted children in such 
special classes [9]. Along with this, there is another point of researchers' view: in terms of the interaction with competitive environment arising in such classes in children, over time, the level of anxiety increases, as a result, in the future, a decrease in their self-esteem and therefore finding gifted people in special classes can negatively affect their psychological development. This is confirmed by the results of a longitudinal study conducted with gifted students of the eleventh and twelfth grades who studied under a special program (two years of living in a hostel) at an American university. Most respondents in this study denied personal giftedness, broadcast low academic self-esteem and a lack of interest in social interactions, at the same time observed that peers more positively accept them than those who were previously [10].

The results of our research have led to the conclusion that at present, new approaches and diagnostic methods are needed to identify giftedness, confirming this phenomenon. In our opinion, the criteria for identifying giftedness cannot currently be measured by existing traditional psychometric techniques, such as tests that determine the intelligence level, which measure the level of mental operations or personal creativity, etc. In light of this, we believe that in order to preserve and improve the giftedness of children, the pedagogical conditions of education, training and their development should meet a set of requirements. Such as, the assessment of different aspects of the behavior and activities of the gifted should be comprehensive; analyze and identify inclinations and interests corresponding to a gifted child in certain areas of activity; giftedness is closely related to the actual mental development of the child, certain signs, which should be disclosed in a timely manner and project its development in the zone of proximal development; use such objective situations that model research activities and allow the child to show maximum independence in mastering and developing activities; analyze the real personal achievements of children and adolescents effective participation in creative competitions, shows and festivals, various subject Olympiads and conferences, etc.

At the same time, we believe that the following conditions should be created for the individual development trajectory of gifted children: stimulation and satisfaction of the children' cognitive activity and interest; pedagogical interaction should provide a positive emotional background for the development of children; a special organization of pedagogical activities with gifted children, taking into account their individual educational trajectory; in teaching gifted children, we propose to develop special educational programs (individual, group, common); in order to develop giftedness in children, we offer an admissible flexible, mobile educational process (content, forms, techniques, teaching methods, etc.) with the possibility of timely adjustment by the students themselves, in accordance with their individual development trajectory; creation of a comfortable educational ecosystem, including an accessible informative environment.

\section{References}

1. A. Ziegler, H. Stoeger, Motivation, Selbstregulation und Leistungsexzellenz, 131 (2011)

2. J. Wai, Intelligence, 203 (2013)

3. J. J. Wu, D. Albanese, Thinking Skills and Creativity, 150 (2010)

4. N.V. Meshkova, Modern Foreign Psychology, 26 (2015)

5. E. A. Sukhacheva, Modern knowledge-intensive technologies, 92 (2008)

6. O.V. Goncharova, Pedagogical conditions for the development of musically gifted children, 215 (2002) 
7. M. Dolores Calero, García-Martin M. Belen, M. Auxiliadora Robles, Learning Potential in high IQ children: The contribution of dynamic assessment to the identification of gifted children (2011)

8. K. B. Rogers, Gifted Child Quarterly, 382 (2007)

9. K. Vogl, F. Preckel, Gifted Child Quarterly, 51 (2014)

10. T. L. Cross, M.A. Gifted Child Quarterly, 25 (2009) 